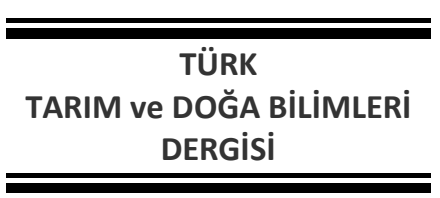

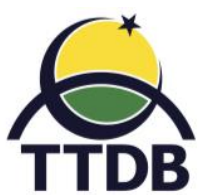

www.dergipark.gov.tr/turkjans

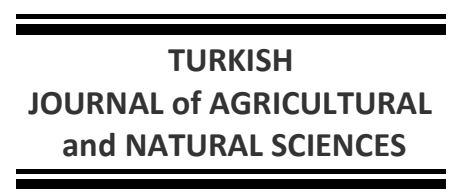

Araştırma Makalesi

\title{
Kayısı (Prunus armeniaca) ve Sandaloz Ağacı (Pistacia lentiscus) Sakızları Eksüdalarının Spektroskopik Karakterizasyonu ve Karşılaştırılması
}

Murat ÇANLI*

Kırşehir Ahi Evran Üniversitesi, Mucur Meslek Yüksekokulu, Kimya ve Kimyasal İ̧̧leme Teknolojileri Bölümü

*Sorumlu yazar: muratbdm@gmail.com

Geliş Tarihi: 19.02.2019

Düzeltme Geliş Tarihi: 25.05.2019

Kabul Tarihi: 26.06 .2019

Özet

Bu çalışmada, kayısı (Prunus armeniaca) ve sandaloz (Pistacia lentiscus) ağacı sakızlarının fizikokimyasal kimyasal bileşimleri belirlenmiştir. Bu polimerik yapıların yapısal bileşen analizleri; UV-Vis spektrofotometreyle, FTIR ve GC-MS ile yapılmıştır. Sonuçta, her iki sakızında bileşiminde de benzer oranlarda arabinoz, ksilitol, galaktoz, ramnoz, mannoz ve üronik asit bulunmuştur. Protein ve terpenoid çeşitleri belirlenmiştir. Birbirlerine göre karşılaştırıldıklarında kayısı sakızı eksüdasının sandaloz sakızı eksüdasına göre daha çok çeşit protein ve terpenoide sahip olduğu görülmüştür.

Anahtar kelimeler: Prunus armeniaca, Pistacia lentiscus, sakız eksüda, kimyasal bileşim, spektroskopik analiz.

\section{Spectroscopic Characterization and Comparison of Exudates of Apricot (Prunus armeniaca) and Mastic/Sandalose Tree (Pistacia lentiscus) Gums}

\begin{abstract}
In this study, physicochemical chemical composition of apricot (Prunus armeniaca) and sandalose (Pistacia lentiscus) tree gums were determined. Structural component analysis has been completed by UV-Vis spectrophotometer, FT-IR and GC-MS. As a result, similar ratios of arabinose, xylitol, galactose, rhamnose, mannose and uronic acid in both gum were found in the composition. Protein and terpenoid varieties were determined. Compared to each other, the apricot gum exudate was found to have more protein and terpenoids than sandalose gum exudate.
\end{abstract}

Key words: Prunus armeniaca, Pistacia lentiscus, gum exudate, chemical composition, spectroscopic analysis.

Giriş

Günümüz endüstriyel kullanımında çoğu termoplastik ve termoset reçine petrolden türevlenmektedir. Bunun sonucunda oluşan gaz emisyonu, atıklar ve geri dönüşüm gibi çevre problemlerini arttırmasının yanında polimer endüstrisi artan petrol fiyatlarından da etkilenmektedir. Bu bağlamda, yenilenebilir kaynakların polimer materyallerinin üretiminde kullanılması artan bir şekilde araştırma faaliyetlerini etkilemektedir (Garrison ve ark, 2016).
Doğal sakızlar, gözyaşı benzeri, çizgili nodüller veya amorf yumrulardaki ağaçlardan ve çalılardan salınır. Doğal olarak kuruduktan sonra, beyazdan soluk/koyu sarıya ve soluk griden koyu kahverengiye kadar farklı renklerde sert ve camsı eksüdalar oluştururlar. En yaygın teoriler, sakızların, iç bitki dokularının sakızlanma denen bir süreç boyunca parçalandığı doğal bir fenomen olarak oluştuğunu söyler. Sakız oluşumu yaz aylarında en hızlı ve bol miktarda bulunur, kışın ise salgıları çok yavaştır ya da yoktur. Leguminosae, Sterculiaceae, Anacardiaceae, 
Combretaceae, Meliaceae, Rutaceae ve Rosaceae gibi çok çeşitli aileler sakız üretmektedir (Bouaziz ve ark, 2016).

Etilen ve etilen açığa çıkaran bileşikler ayrıca çekirdekli meyve ağaçları ve kayısı (Prunus armeniaca L.) gibi Rosaceae ailesi meyvelerinde sakız oluşumuna neden olurlar. Kayısı sakızındaki polisakkaritler, galaktoz (Gal) ve arabinoz (Ara) çoğunluğu oluşturmak üzere ve az miktarda ksiloz (Xyl) içeren karbonhidrattan oluşmaktadır (Saniewski ve ark., 2002).

Arabik sakızın maliyet ve kullanılabilirlik dalgalanmaları, iyi fonksiyonel özelliklere sahip yeni doğal hidrokolloid zamklar aramak için güçlü nedenlerdir (Mahfoudhi ve ark., 2012).

Prunus cinsi, Rosaceae familyasına ait olup şeftali (P. Persica), kayısı (P. Armeniaca), mürdüm eriği (P. İnsitia), kiraz (P. cerasus) gibi birçok meyve taşıyan ağaç içerir. Bu türler, meyve ve gövdelerindeki bir hastalık (gummosis), gövdedeki bir hasardan veya budamadan sonra mikrobiyal saldırıdan sonra ortaya çıkan bol miktarda sakız eksüdası üretirler. Bu eksüdalar, polisakkarid bileşenlerinden ve daha az miktarda Ara, Xyl, Gal, ramnoz (Rhm), mannoz (Man) ve üronik asitten oluşabilir. Yapısal değişimler, monosakkaritler ve glikozidik bağların oranına bağlıdır (Simas ve ark, 2008).

Rosaceae ailesinin sakız eksüdaları Gal, Ara ve glukuronik asit (Glu) gibi karbonhidratların yoğun olduğu bileşiklerden oluşmaktadır (Bouaziz ve ark, 2016). Bunlardan Ara, beş karbon içeren aldozlar anlamına gelen aldopentozların bir üyesi olup $\left(\mathrm{C}_{5} \mathrm{H}_{10} \mathrm{O}_{5}\right)$, bir aldehit $(\mathrm{CHO})$ grubu içerir. Bilimsel adı ksilitol $\left(\mathrm{C}_{5} \mathrm{H}_{12} \mathrm{O}_{5}\right)$ olan şeker alkolü selüloz içeren çeşitli ürünlerden elde edilmektedir. $\mathbf{G a l}\left(\mathrm{C}_{6} \mathrm{H}_{12} \mathrm{O}_{6}\right)$, glikoz ve fruktoz gibi bir monosakkarittir. Üronik asit, bir şeker dizisindeki son karbonun olduğu alkolik grubun oksitlenmesi sonucu-COOH grubu oluşmasıyla elde edilen bir şeker asittir.

Bunların yanında sakız eksüdası yapısının içerisinde protein ve terpenoidler de yer almaktadır. Bu nedenlerden dolayı, bu çalışmada kayısı sakızı ve sandaloz sakızı eksüdalarının kimyasal bileşimleri karbonhidratlar, proteinler ve terpenoidler yönünden incelenmiştir. Ayrıca, her iki sakız örneğinin birbirleri ile karşılaştırmaları da yapılmıştır.

\section{Materyal ve Yöntem}

Sakız eksüdaları Kırşehir'in Mucur ilçesinde yer alan kayısı ağaçları (Prunus armeniaca) ve Muğla'nın Datça ilçesinde yer alan sandaloz ağaçlarından (Pistacia lentiscus) toplanmıştır (Şekil 1). Ağaç gövdesinden toplanan sakızlardan $2 \mathrm{~g}$ alınıp $100 \mathrm{ml}$ saf su içerinde 1 gece boyunca bekletildi (Simas ve ark, 2008). Hazırlanan örnekler, UV-vis spektrofotometresiyle yapıdaki kalıntı monomer, protein, antioksidan ve benzeri safsızlıklar tespit edilmiştir.

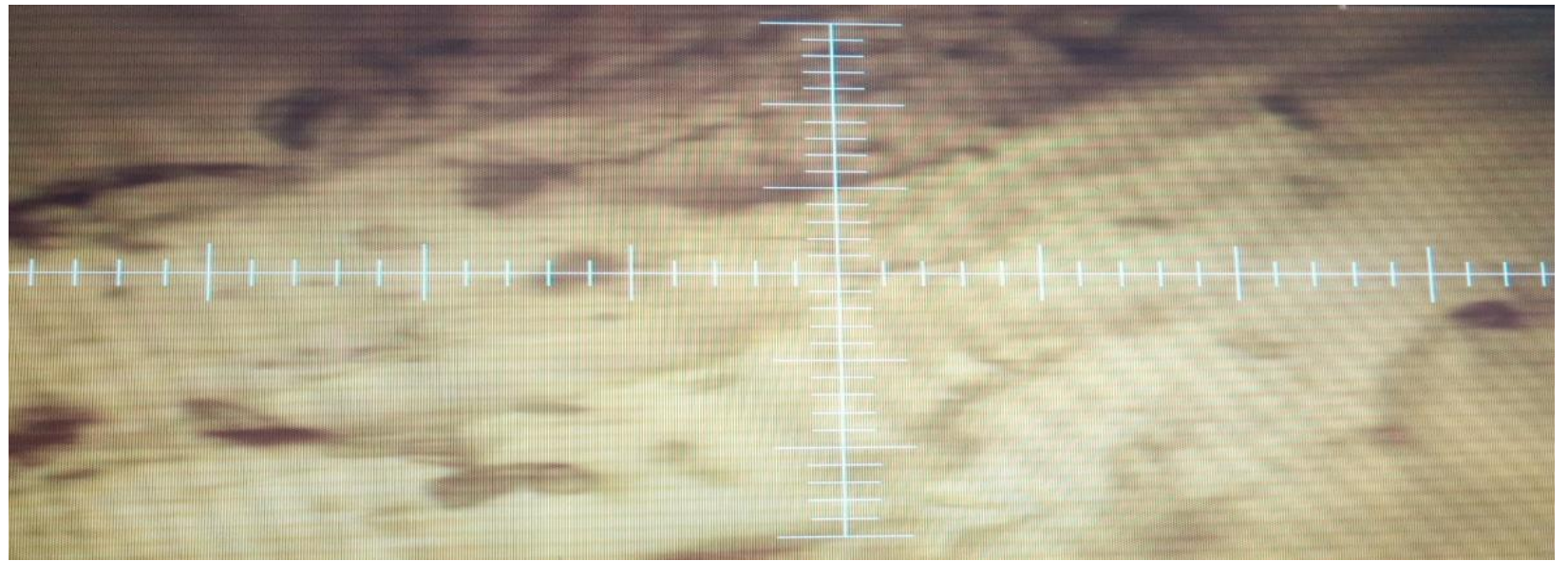

Şekil 1. Sakızın mikroskoptaki 40 x görüntüsü.

Sakız eksüdalarının yapılarındaki protein ve üronik asit varlığı UV-Vis spektrometresiyle (Shimadzu, UV 1201) taranırken tarama aralığı 200$850 \mathrm{~nm}$ arasında tutulmuştur.

FT-IR ve GC-MS spektrometresiyle yapıdaki gruplar belirlenmiştir. Fonksiyonel grupların varlığı kızılötesi spektroskopi ile analiz edildi. Kurutulmuş $P$. cerasoides sakızının tozundan yaklaşık $10 \mathrm{mg}$ alınmış ve transdusyon oranı değerleri 400 ile $4000 \mathrm{~cm}^{-1}$ arasında FT-IR spektrofotometre (Alpha FTIR Spectrometer, Bruker) ile kaydedilmiştir.

Analiz şartları Daferera ve ark. (2000) önerdiği gibi ayarlanmıştır. GC-MS analizi için çözücü olarak merkaptanol ve su kullanılmıştır. Monosakkarit 
bileşimini belirlemek için örnek asit ile hidroliz edilerek metil glikosit haline getirilmiştir. Elektronik kontrollü bölünmemiş enjeksiyon portu ile donatılmış bir gaz kromatografisi 6890 (Agilent, ABD) ve elektron darbeli iyonizasyon odası ile tek bir dört kutuplu inert kütle seçici detektör (5973, Agilent, ABD) ile birleştirilen GC-MS analizi için kullanıldı. GC ayırma bir DB-624 kılcal kolonda (60 m x 0,25 mm x 1,4 um) (J \& W Scientific, ABD) gerçekleştirilmiştir. Helyum sabit bir basınç 25,6 psi olan taşıyıcı gazdı. Örnek çözeltinin yaklaşık $1 \mu L^{\prime}$ si $260{ }^{\circ} \mathrm{C}$ 'de ayrık modda enjekte edildi. Fırının başlangıç sıcaklığı $150{ }^{\circ} \mathrm{C}$ idi ve $260{ }^{\circ} \mathrm{C}$ ye ulaşana kadar dakikada $10{ }^{\circ} \mathrm{C}$ 'lik bir hızla yükseldi. Sıcaklık, 25 dakikadan daha az olmamak üzere 260 ${ }^{\circ} C^{\prime}$ de tutuldu. Kütle spektrometrik parametreleri, 69,9 eV elektron darbe iyonizasyon enerjisi, $230{ }^{\circ} \mathrm{C}$ iyon kaynağı sıcaklığı ve $150{ }^{\circ} \mathrm{C}$ MS kuadrupol sıcaklığı ile ayarlandı. MS sistemi, rutin olarak seçici iyon izleme modunda ayarlandı. Hedef piklerin atamaları orijinal malzemelerle doğrulandı.

\section{Bulgular ve Tartışma}

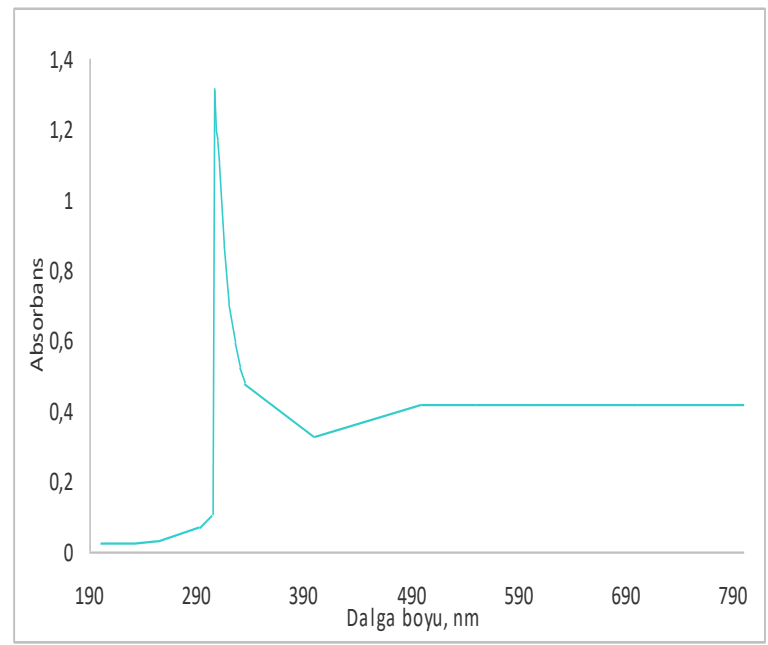

Proteinlerin absorpsiyon sepktrumu ultraviyole bölgede 185-320 nm arasında olduğu (Prasad ve ark, 2017), sakız eksüdasının sulu çözeltisinin bu dalga boylarında protein absorpsiyonundan dolayı bir absorpsiyon piki verdiği bilinmektedir (Malsawmtluangi ve ark, 2014). Bu araştırma için toplanan örneklerin UV-Vis spektrometresinde yapılan ölçümlerinde $\lambda_{\max }=306$ $\mathrm{nm}$ de bir maksimum verdiği her iki sakız numunesi içinde bulunmuştur (Şekil $2 \mathrm{a}$ ve $2 \mathrm{~b}$ ). $\mathrm{Bu}$ dalga boyundaki pik, aromatik amino asit bileşiğindeki karboksilatta yer alan oksijen atomundaki eşlenmemiş elektronların $\pi-\pi^{*}$ geçişindeki titreşimi verir (Su, 2013). Ayrıca $540 \mathrm{~nm}$ de görülen pik ise proteinin kuyruk uzantısının belirtecidir ve üronik asitin varlığının göstergesidir (Malsawmtluangi ve ark, 2014). Bu belirteç sandaloz sakızı eksüdasında daha belirgin bir şekilde ortaya çıkmıştır. Glutamik asit, glisin, fenilalanin, lösin, prolin, alanin, izolösin, histidin, treonin, serin, sistein, metiyonin, triptofan ve lizin proteinleri kayısı sakızı eksüdasında belirlenirken, glutamik asit, glisin, alanin, histidin, treonin, serin ve sistein sandaloz sakızı eksüdasında belirlenmiştir.

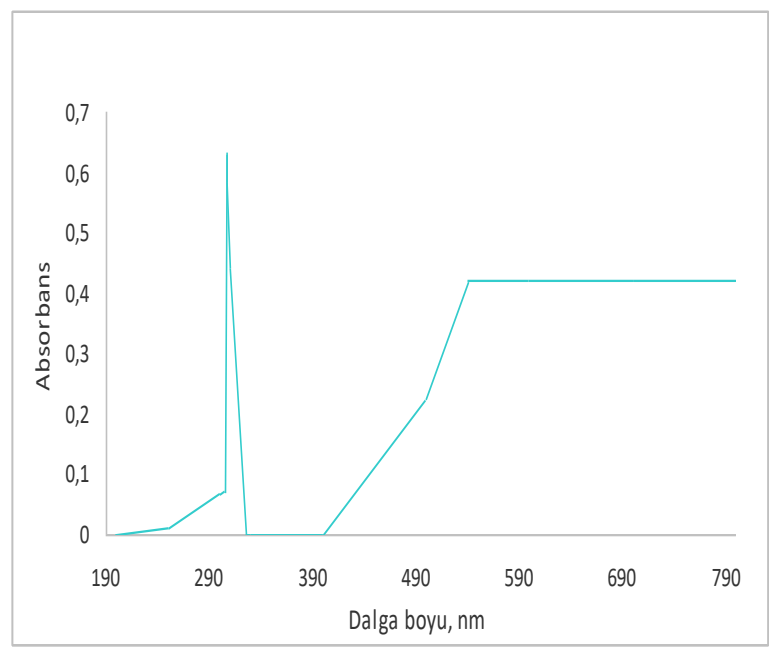

b

Şekil 2. (a) Kayısı ve (b) Sandaloz ağacı sakızı için UV-Vis absorbans grafiği.

Her iki sakız eksüdasının alınan FT-IR spektrumları incelendiğinde (Şekil 3 ve 4) $1740 \mathrm{~cm}^{-1}$ (kayısı için) ve $1704 \mathrm{~cm}^{-1}$ de (sandaloz için) keskin bir pik spesifik $\mathrm{C}=\mathrm{O}$ grubunun varlığına kanıt olmaktadır (Pagola ve ark, 2003). Aynı zamanda, 2500-3100 cm-1 arasında beliren pikler yapıda karboksilli asitlerin varlığını göstermektedir. Bu pikler sandaloz sakızı numunesi için $2927 \mathrm{~cm}^{-1}$ ve $2866 \mathrm{~cm}^{-1}$ ve kayısı sakızı numunesi için $2922 \mathrm{~cm}^{-1}$ de belirmiştir.
Sakızın yapısında beliren ve hidrokarbonun solunda yer alan alkol (O-H gerilim) pikleri de 3000$3700 \mathrm{~cm}^{-1}$ çıkmaktadır. Bu alkol piklerinin genel özelliği yoğun ve düzgün bir eğri şeklinde olmalarıdır. Her iki sakız türünün spektrumlarında $3500-3200 \mathrm{~cm}^{-1}$ ve $1150-1000 \mathrm{~cm}^{-1}$ de güçlü pikler görülmektedir. Bunun yanında, örnekler 1000 ve $750 \mathrm{~cm}^{-1}$ arasında nispeten daha az kuvvetli pikler vermiştir. 3500-3200 $\mathrm{cm}^{-1}$ arasındaki pikler $\mathrm{O}-\mathrm{H}$ da yer alan hidrojen bağının 
hidroksil grubu gerilim titreşiminden kaynaklanmaktadır.

$1085-1050 \mathrm{~cm}^{-1}$ arasındaki pikler $\mathrm{C}-\mathrm{OH}$ gerilim titreşiminden kaynaklanmaktadır ki burada kayısı sakızı eksüdası için $1022 \mathrm{~cm}^{-1}$ olarak belirmiştir. Bu pik alisikilik alkollere ve primer doygun alkollere işaret etmektedir. Aynı zamanda, $1000-1300 \mathrm{~cm}^{-1}$ arasında şeker yapısında bulunan halkada yer alan eterden dolayı da bu pik oluşur. Alkil ve alisiklik alkollere benzer şekilde kayısı sakızı eksüdasında kuvvetli iki pik (1230 ve $1022 \mathrm{~cm}^{-1}$ ) sandaloz sakızı eksüdasında (1204 $\mathrm{cm}^{-1}$ ve $883 \mathrm{~cm}^{-1}$ ) daha az kuvvetli 2 pik olmak üzere her iki örnekte 1350 ve $750 \mathrm{~cm}^{-1}$ arasında pik vermişlerdir (Urbanski ve ark., 1959).

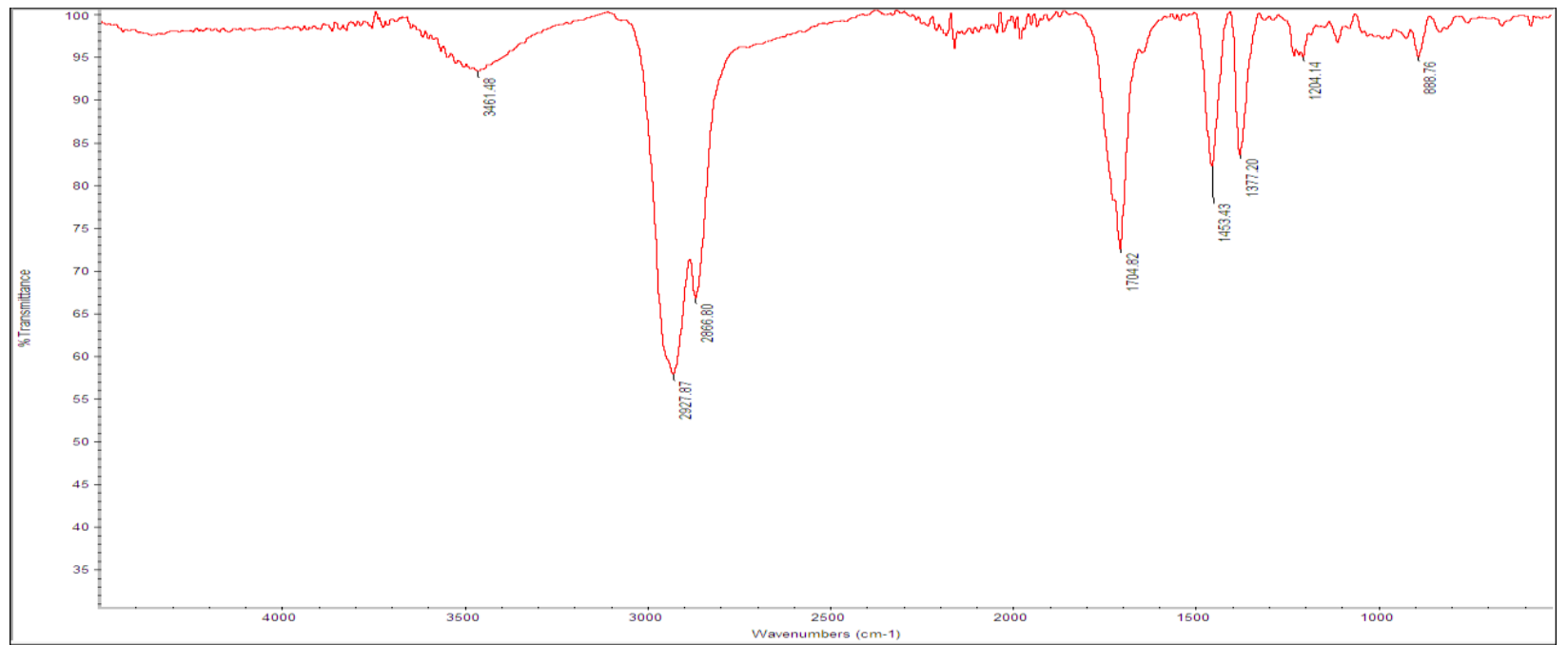

Şekil 3. Sandaloz sakızı eksüdası için FT-IR spektrumu.

Çizelge 1'de literatürde yer alan bazı çalışmalardaki seçilen ağaçların sakızlarının eksüdaları için karbonhidrat içerikleri verilmiş ve bunlar bu çalışmada kullanılan ağaçların sakızlarının içerikleriyle karşılaştırılmıştır.

Çizelge 1. Çeşitli sakız eksüdalarının monosakkarit bileşimleri

\begin{tabular}{|c|c|c|c|c|c|c|}
\hline & $\begin{array}{c}\text { Ramnoz, } \\
\% \\
\end{array}$ & $\begin{array}{c}\text { Ksiloz, } \\
\%\end{array}$ & $\begin{array}{c}\text { Arabinoz, } \\
\%\end{array}$ & $\begin{array}{c}\text { Galaktoz, } \\
\% \\
\end{array}$ & $\begin{array}{c}\text { Mannoz, } \\
\%\end{array}$ & $\begin{array}{l}\text { Üronik } \\
\text { asit, \% }\end{array}$ \\
\hline $\begin{array}{l}\text { Kayısı ağacı sakızı } \\
\text { (Bu çalışmada) }\end{array}$ & 0.57 & 8.73 & 71.9 & 17.1 & 0.69 & 1.00 \\
\hline $\begin{array}{l}\text { Sandaloz ağacı sakızı } \\
\text { (Bu çalışmada) }\end{array}$ & 0.53 & 9.15 & 76.9 & 12.0 & 0.49 & 0.87 \\
\hline $\begin{array}{l}\text { Kiraz ağacı sakızı (Lluveras-Tenorio ve } \\
\text { ark, 2012) }\end{array}$ & 15 & 0 & 34 & 49 & 0 & 12 \\
\hline $\begin{array}{l}\text { Malva nut sakızı (Mirhosseini ve Amid, } \\
\text { 2012) }\end{array}$ & 29.4 & 2.1 & 32 & 29.2 & 4.8 & - \\
\hline Kayısı ağacı sakızı (Fathi ve ark, 2016) & 2.5 & 17.8 & 41.5 & 23.7 & 14.4 & - \\
\hline Badem ağacı sakızı (Fadavi ve ark, 2014) & 1.1 & 6.8 & 61.1 & 28.4 & 0.3 & 1.7 \\
\hline Şeftali ağacı sakızı (Simas ve ark, 2008) & Çok az & 7 & 36 & 42 & 2 & 13 \\
\hline Kayısı ağacı sakızı (Rosik, 1968) & - & 2 & 21 & 26 & 1 & 10 \\
\hline $\begin{array}{l}\text { Kiraz ağacı sakızı (Malsawmtluangi ve } \\
\text { ark, 2014) }\end{array}$ & 1.4 & 1.2 & 61 & 5.4 & - & - \\
\hline Ghatti sakızı (Pitthard ve Finch, 2001) & - & 8.5 & 63.5 & 24.6 & 3.3 & - \\
\hline
\end{tabular}

Brezilya'nın Palmas bölgesinde yer alan şeftali ağaçlarından elde edilen sakız eksüdasının monosakkarit bileşimi (w/w); \%36 Ara, \%7 Xyl, \% 2 Man, \%42 Gal ve \%13 Üronik asit olarak bulunmuştur
(Simas ve ark., 2008). İtalya'nın çeşitli bölgelerinde toplanan kiraz sakızı eksüdası için değerler (w/w); \%50 Ara, \%11 Xyl, \%2 Man, \%2 Rhm ve \%34 Gal olarak belirlenmiştir (Lluveras-Tenorio ve ark., 2012). 
Rosik (1968) çalışmasında kayısı sakızı üzerine odaklanmış ve sonuçları Ara için \%21 ve Gal için \%26 olarak bulmuştur. Benzer şekilde, Fathi ve ark. (2016) İran'da yer alan kayısı ağaçlarından topladıkları sakızlarda (w/w); \%41,5 Ara, \%17,8 Xyl, \%14,4 Man,
$\% 2,5 \mathrm{Rhm}$ ve \%23,7 Gal oranlarında monosakkarit tespit etmişlerdir. Bu çalışmada ise, kayısı sakızı eksüdası için Ara, Xyl, Gal, Rhm, Man ve üronik asit miktarları yüzde olarak sırasıyla (71,9: 8,73: 17,1: 0,57: 0,69: 1,00 (w/w)) değerlerinde görülmüştür.

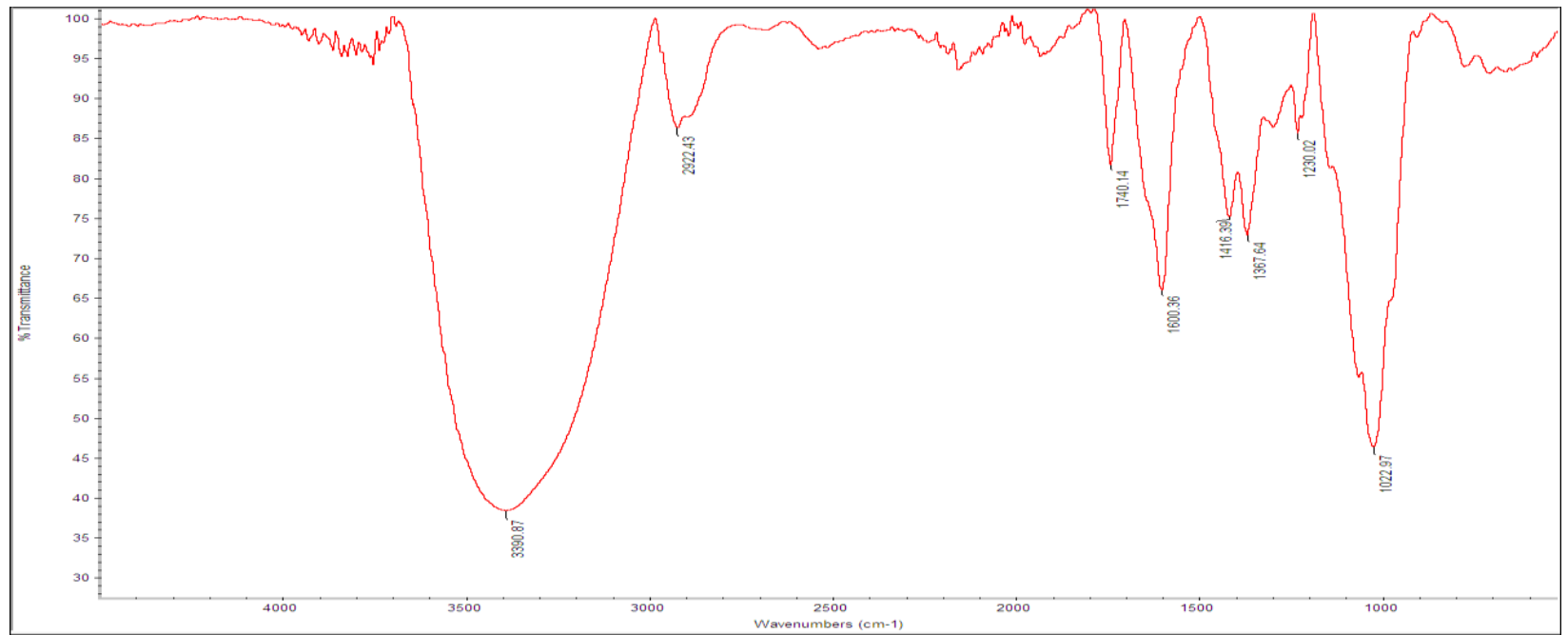

Şekil 4. Kayısı sakızı eksüdası için FT-IR spektrumu.

Kottakis ve ark. (2008) Chios sandaloz sakızının eksüdası içerisinde temel olarak (w/w) Ara $(\% 51,1)$ ve Gal (\% 48,9) bulunduğunu belirtmişlerdir. Bu çalışmada ise, Ara, Xyl, Gal, Rhm, Man ve üronik asit miktarları sandaloz sakızı eksüdası için sırasıyla, (\% 76,9: 9,15: 12,0: 0,53: 0,49: 0,87 (w/w)) olarak bulunmuştur.
Alıkonma süresi (Retention time) kayısı sakızı ve sandaloz sakızı için; 21, 24, 36, 40, 52 ve 57 dakikalarda oluşmuştur (Şekil 5 ve 6). Bu piklerin aynı sürelerde meydana gelmesi her iki sakız eksüdasında da aynı karbonhidratların bulunduğunun göstergesidir. Bu alıkonma sürelerinde sırasıyla Rhm, Xyl, Ara, Man, Gal ve üronik asidi işaret etmektedir.

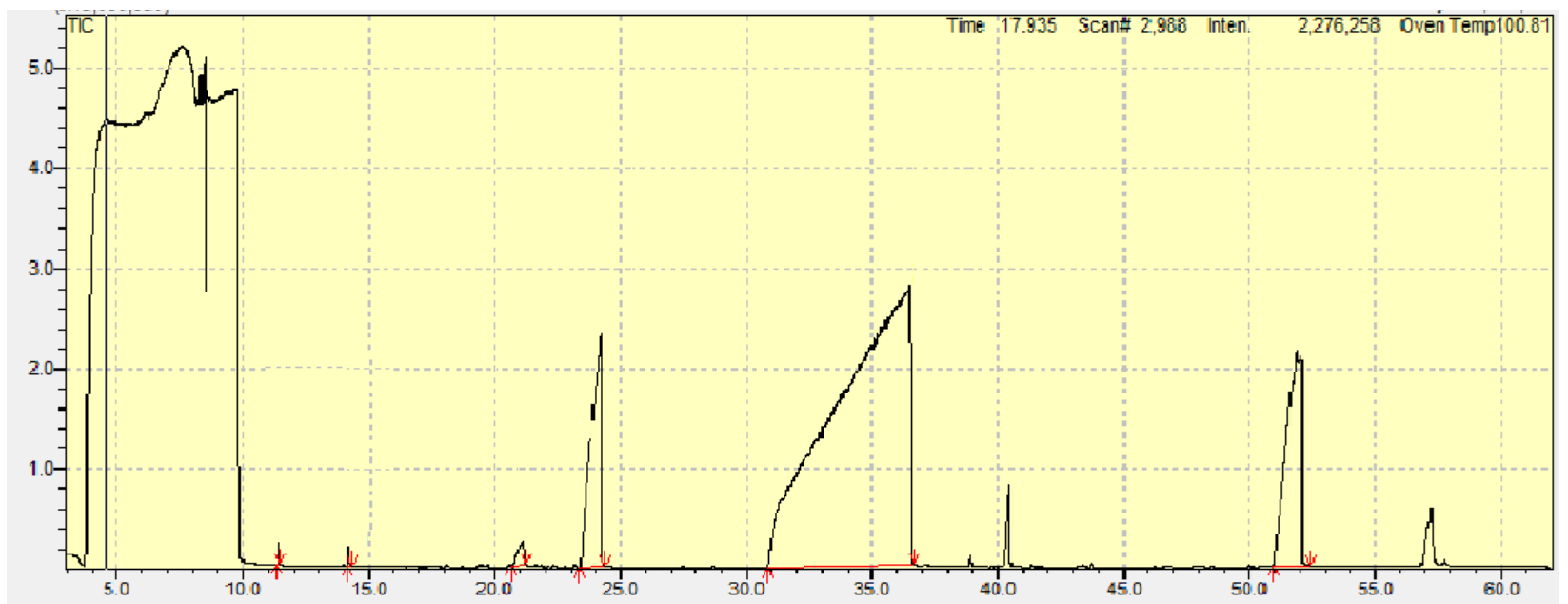

Şekil 5. Sandaloz sakızının GC-MS grafiği.

Sandaloz ağacının sakızı üzerine yapılan çalışmalar daha çok sakızın içerisinde yer alan yağın bileşimini bulmaya yönelik olmuştur. Fas'ın doğusunda yer alan Sandaloz ağacından (Pistacia lentiscus L.) elde edilen yağın $\mathrm{C}_{10} \mathrm{H}_{16}$ formülünde farklı dizilişe sahip ana bileşenleri (w/w); mirsen $(\% 39,2)$, limonen $(\% 10,3)$, gurjunen $(\% 7,8)$, germakren $(\%$ $4,3)$, $\alpha$-pinen (\% 2,9), ve muurolen (\% 2,9) olarak tespit 
edilmiştir (Amhamdi ve ark, 2009). Cezayir'in farklı bölgelerinden toplanan sandaloz ağacı (Pistacia lentiscus L.) sakızından elde edilen yağın bileşiminde longifolen (\% 12,8 - 16,4 (w/w) arasında değişen oranlarda) ve $\alpha$-pinen (\% 19,0 (w/w) civarında) en yüksek miktardaki bileşen olarak bulunmuştur. GC-MS ile yapılan ölçümlerde ayrıca $\gamma$-kadinen, trans- $\beta$ terpineol, terpinen-4-ol, sabinen, ve $\beta$-pinen önemli bileşenler olarak bulunmuştur (Dob ve ark, 2006).

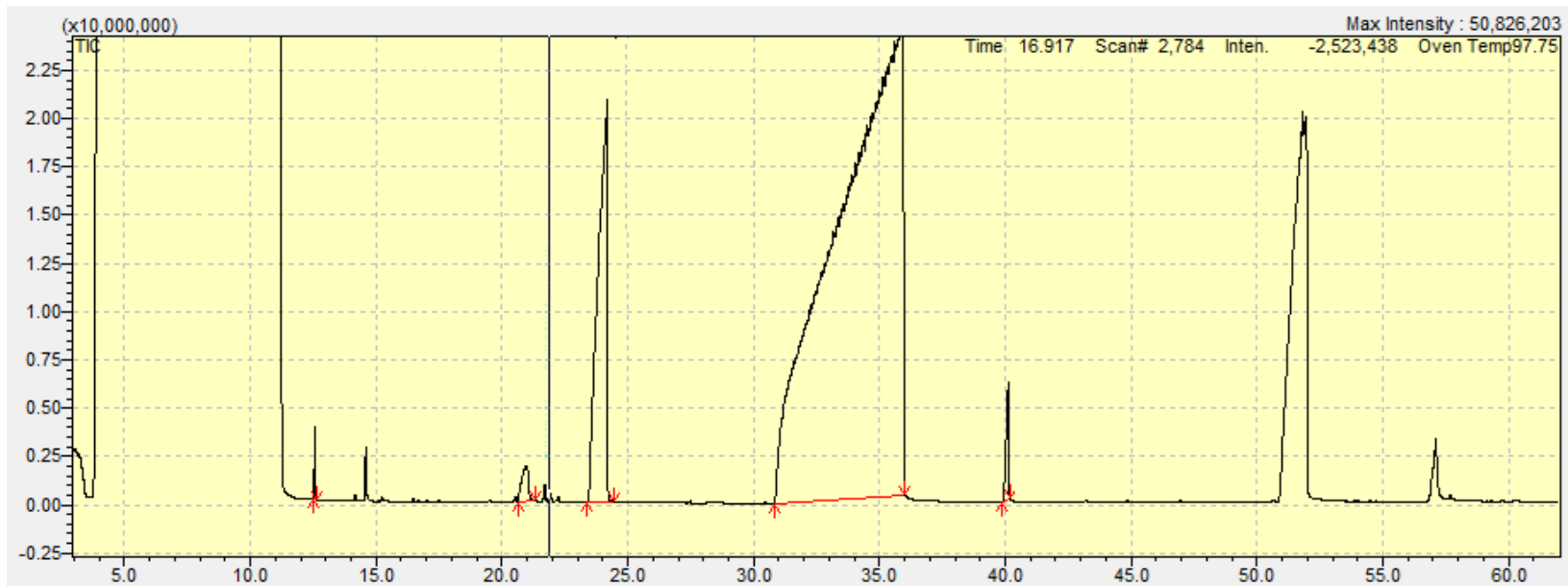

Şekil 6. Kayısı sakızının GC-MS grafiği.

Pistacia vera, Pistacia terebinthus, ve Pistacia lentiscus diye bilinen türün ağaç yapraklarından elde edilen yağın GC ve GC-MS analizlerinde $\alpha$-pinen, $\beta$ pinen, limonen, terpinen-4-ol ve $\alpha$-terpineol ana bileşenler olarak bulunmuştur (Duru ve ark, 2003). Bunlardan Pistacia lentiscus var. chia, diye bilinen sandaloz ağacının yağı ve sakız eksüdasında $\alpha$-pinen, $\beta$-mirsen, $\beta$-pinen, limonen ve $\beta$-karyofilin bileşikleri tanımlanmıştır (Koutsoudaki ve ark., 2005). Pistacia lentiscus L.'nin sakızının kimyasal bileşiminin \%90 (w/w) monoterpen hidrokarbon içerdiği ve ana bileşenlerinin \%79 (w/w) $\alpha$-pinen ve \%3 (w/w) $\beta$ mirsen olduğu tespit edilmiştir (Bouaziz ve ark, 2016). Bu çalışmada ise; kayısı sakızı için $\alpha$-pinen, trans- $\beta$ terpineol, $\beta$-mirsen, farnesol, limonen, ve sandaloz sakızı için $\alpha$-pinen, trans- $\beta$-terpineol, $\beta$-mirsen, limonen bileşikleri tespit edilmiştir.

Her iki ağacın sakızları karşılaştırıldığında, sandaloz ağacının daha yüksek oranda Ara ve Xyl bileşenine sahip olduğu görülmektedir. Kayısı ağacı sakızının daha yüksek oranda Gal içeriğine sahip olmasına karşın her iki ağacın sakızlarındaki yüksek oranda Ara, Gal ve üronik asit içeriği sakız yapısında pektin oluşumunun yüksek oranda olduğunun göstergesidir (Gül ve Dizlek, 2009). UV-Vis spektrumlarında beliren iki pik her iki sakız örneği için de karboksilli asit ve protein içeriğini işaret etmektedir. FT-IR analizi ise yapıda karboksil, hidroksil ve metil gruplarının varlığını göstermiştir.

\section{Sonuç ve Öneriler}

Kayısı sakızı ve sandaloz sakızı eksüdalarının kimyasal bileşiminde ana bileşen karbonhidratlar olarak ortaya çıkmıştır. GC-MS analizinde Ara, Gal, $X y l$, Man ve Rhm bulunmuştur. Her iki ağacın sakız eksüdalarının bileşimleri dikkate alındı̆̆ında UV-vis daki piklerinde aynı dalga boyunda ve benzer IR pikleri vermelerine karşın kayısı sakızının suda daha iyi çözündüğü görülmüştür. Bunun yapılarında bulunan farklı protein çeşitlerine sahip olmalarından kaynaklandığı düşünülmektedir. Diğer yapılan çalışmalarda kullanılan sakız eksüdalarına göre karşılaştırıldıklarında yüksek Ara bileşime sahip olmaları en öne çıkan özellikleridir. Türkiye'nin değişik yerlerindeki ağaçlardan elde edilecek sakız eksüdalarının benzer bir oluşumu gösterip göstermedikleri de değerlendirmeye alınabilecek bir başka araştırma konusu olacaktır. Kayısı sakızının ve sandaloz sakızının polimer kompozitlere katkıları daha sonraki çalışmalarda araştırılacaktır.

\section{Teşekkür}

Bu çalışmaya desteklerinden dolayı Kırşehir Ahi Evran Üniversitesi Bilimsel Araştırma Projeleri Birimine (MMY.A3.16.001) teşekkür ederim.

\section{Kaynaklar}

Amhamdi, H., Aouinti, F., Wathelet, J. P., Elbachiri, A. 2009. Chemical composition of the essential oil of 
Pistacia lentiscus L. from Eastern Morocco. Records of Natural Products, 3(2): 90- 95.

Bouaziz, F., Koubaa, M., Ghorbel, R.E., Chaabouni, S. E. 2016. Recent advances in Rosaceae gum exudates: From synthesis to food and non-food applications. International Journal of Biological Macromolecules, 86: 535-545.

Daferera, D.J., Ziogas, B.N., Polissiou, M.G. 2000. GC-MS Analysis of essential oils from some Greek aromatic plants and their fungitoxicity on Penicillium digitatum. Journal of Agricultural and Food Chemistry, 48: 2576-2581.

Dob, T., Dahmane, D., Chelghoum, C. 2006. Chemical composition of the essential oils of Pistacia lentiscus L. from Algeria. Journal of Essential Oil Research, 18: 335-338.

Duru, M. E., Cakir, A., Kordali, S., Zengin, H., Harmandar, M., Izumi, S., Hirata, T. 2003. Chemical composition and antifungal properties of essential oils of three Pistacia species. Fitoterapia, 74: 170-176.

Fadavi, G., Mohammadifar, M.A., Zargarran, A., Mortazavian, A.M., Komeili, R. 2014. Composition and physicochemical properties of Zedo gum exudatesfrom Amygdalus scoparia. Carbohydrate Polymers, 101: 1074-1080.

Fathi, M., Mohebbi, M., Koocheki, A. 2016. Some physico-chemical properties of Prunus armeniaca L. Gum exudates. International Journal of Biological Macromolecules, 82: 744750.

Garrison, T. F., Murawski, A., ve Quirino, R. L. 2016. BioBased Polymers with Potential for Biodegradability. Polymers, 8(7): 262, https://doi.org/10.3390/polym8070262,

Gül, H., Dizlek, H. 2009. Pentozanların kimyasal bileşimleri ve yapıları. Gıda, 34(1): 37-42.

Kottakis, F., Lamari, F., Matragkou, C., Zachariadis, G., Karamanos, N., Choli-Papadopoulou, T. 2008. Arabino-Galactan Proteins from Pistacia lentiscus var. chia: isolation, characterization and biological function. Amino Acids, 34: 413-420.

Koutsoudaki, C., Krsek, M., Rodger, A. 2005. Chemical Composition and antibacterial activity of the essential oil and the gum of Pistacia lentiscus var. chia. Journal of Agricultural and Food Chemistry, 53(20): 7681-7685.

Lluveras-Tenorio, A., Mazurek, J., Restivo, A., Colombini, M. P., Bonaduce, I. 2012. Analysis of plant gums and saccharide materials in paint samples: comparison of GC-MS analytical procedures and databases. Chemistry Central Journal, 6: 1-15, https://doi.org/10.1186/1752-153X-6-115.
Mahfoudhi, N., Chouaibi, M., Donsi, F., Ferrari, G., Hamdi, S. 2012. Chemical composition and functional properties of gum exudates from the trunk of the almond tree (Prunus dulcis). Food Science and Technology International, 18(3): 241-250.

Malsawmtluangi, C., Thanzami, K., Lalhlenmawia, H., Selvan, V., Palanisamy, S., Kandasamy, R. 2014. Physicochemical characteristics and antioxidant activity of Prunus cerasoides D. Don gum exudates. International Journal of Biological Macromolecules, 69: 192-199.

Mirhosseini, H., Amid, B.T. 2012. A review study on chemical composition and molecular structure of newly plant gum exudates and seed gums. Food Research International, 46: 387-398.

Pagola,, S., Benavente, A., Raschi, A., Romano, E., Molina, M.A.A., Stephens, P.W. 2003. Crystal Structure Determination of Thymoquinone by HighResolution X-Ray Powder Diffraction. AAPS Pharm Sci. Tech., 5(2): 24-31.

Pitthard, V., Finch, R. 2001. GC-MS Analysis of monosaccharide mixtures as their diethyl dithioacetal derivatives: Application to plant gums used in art works. Chromatographia, 53(1): 317-321.

Prasad, S., Mandal, I., Singh, S., Paul, A., Mandal, B., Venkatramani, R., Swaminathan, R. 2017. Near UV-Visible electronic absorption originating from charged amino acids in a monomeric protein. Chemical Science, 8: 5416-5433.

Rosik, J. 1968. Structural features of the polysaccharide of apricot gum in dependence on the infection with fungi, application of a synthetic material and vegetative period. Acta Horticulturae, 11: 523528.

Saniewski, M., Ueda, J., Horbowicz, M., Miyamoto, K., Puchalski, J. 2002. Gum in apricot (Prunus armeniaca L) shoots induced by methyl jasmonate. Acta Agrobotanica, 54(2): 27-34.

Simas, F.F., Gorin, P.A.J., Wagner, R., Sassaki, G.L., Bonkerner, A., lacomini, M. 2008. Comparison of structure of gum exudate polysaccharides from the trunk and fruit of the peach tree (Prunus persica). Carbohydrate Polymers, 71: 218228.

Su, W. F. 2013. Principles of Polymer Design and Synthesis. Lecture notes in Chemistry. Chapter 5, Springer, Berlin, Heidelberg, Germany, 89-110.

Urbanski, T., Hofman, W., Witanowski, M. 1959. The infrared spectra of some carbohydrates. Bulletin de L'academie Polonaise Des Sciences, 7(9): 619624. 